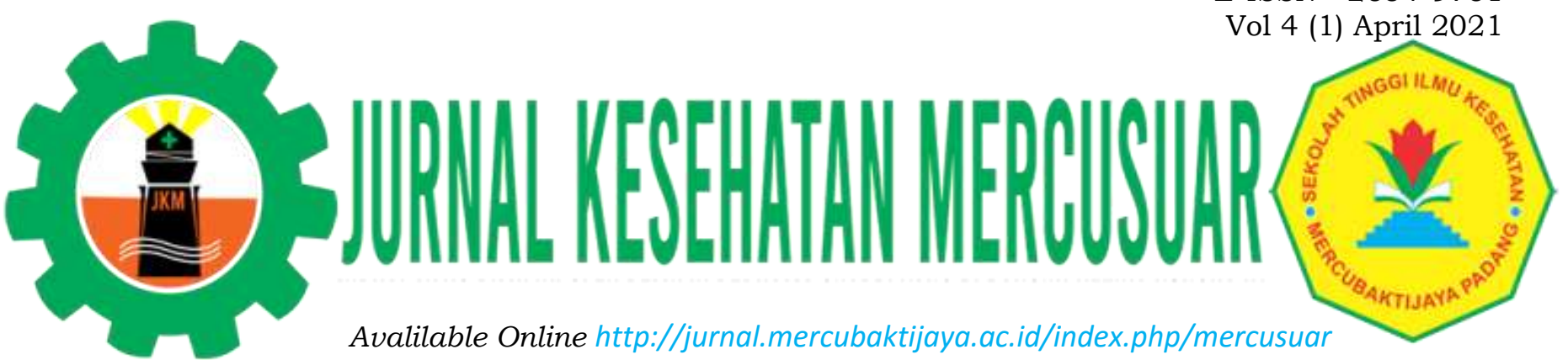

\title{
FAKTOR-FAKTOR YANG BERHUBUNGAN DENGAN KEPATUHAN IBU DALAM IMUNISASI BAYI USIA 0-12 BULAN
}

\author{
Vivi Syofia Sapardi“", Velga Yazia², Mira Andika ${ }^{3}$ \\ ${ }^{1 * 2,3}$ STIKes MERCUBAKTIJAYA Padang \\ *Email Penulis Korespondensi: vivisyofia1984@gmail.com
}

\begin{abstract}
The prevalence of basic immunization in Indonesia in 2018 was $86.9 \%$. This is influenced by several factors including the level of knowledge, affordability of the house to health services, and family support. The impact that can be caused if the baby does not fulfill the complete basic immunization is that the baby will suffer from a disease that may cause disability or death. This study aims to analyze the factors associated with maternal compliance in fulfilling basic immunization for infants aged 0-12 months. This study used a cross sectional study design with 93 respondents. Data collection was carried out on March 2-14 2020 by visiting the respondent's house and giving a questionnaire to the respondent. This study uses the Chi-Square statistical test. The results of this study found that $55.9 \%$ of mothers were not obedient, $60.2 \%$ of low knowledge, affordability of immunization services near $71.0 \%$, 57\% of families did not support The results obtained There is a relationship between knowledge and maternal compliance with a $p$ value of 0.019. There is no relationship between the affordability of immunization services and maternal compliance with a p value of 0.518 . There is a relationship between family support and maternal compliance with a $p$ value of 0.013. The factor of knowledge, family support affects the provision of basic immunization to infants. It is hoped that puskesmas and other health workers can increase posyandu activities and provide counseling on the importance of providing basic immunization to infants.
\end{abstract}

Keywords: Family support; Immunization; Affordability of service places; Maternal compliance; Knowledge

\begin{abstract}
ABSTRAK
Prevalensi imunisasi dasar di Indonesia tahun 2018 sebesar 86,9\%. Hal ini dipengaruhi oleh beberapa faktor diantaranya tingkat pengetahuan, keterjangkauan jarak rumah ke pelayanan kesehatan, dan dukungan keluarga. Dampak yang dapat ditimbulkan jika bayi tidak mencukupi imunisasi dasar lengkap adalah bayi akan menderita penyakit yang kemungkinan dapat menyebabkan kecacatan atau kematian. Penelitian ini bertujuan untuk menganalisis faktor-faktor yang berhubungan dengan kepatuhan ibu dalam melakukan pemenuhan imunisasi dasar pada bayi usia $0-12$ bulan. Penelitian ini menggunakan desain cross sectional study dengan responden 93 orang. Pengumpulan data dilaksanakan tanggal 2 -14 Maret 2020 dengan cara ke rumah responden dan memberikan kuesioner kepada responden. Penelitian ini menggunakan uji statistic Chi-Square. Hasil penelitian ini didapatkan 55,9\% ibu tidak patuh, pengetahuan rendah $60,2 \%$, keterjangkauan tempat pelayanan imunisasi dekat 71,0\%, keluarga tidak mendukung 57\%. Adapun hasil didapatkan ada hubungan antara
\end{abstract}


pengetahuan dengan kepatuhan ibu dengan nilai $p$ value $=0,019$. Tidak terdapat hubungan antara keterjangkauan tempat pelayanan imunisasi dengan kepatuhan ibu dengan $p$ value $=$ 0,518 . Terdapat hubungan antara dukungan keluarga dengan kepatuhan ibu dengan $p$ value $=$ 0,013. Faktor pengetahuan, dukungan keluarga mempengaruhi pemberian imunisasi dasar pada bayi. Diharapkan bagi puskesmas dan tenaga kesehatan lainnya dapat meningkatkan kegiatan posyandu dan memberikan penyuluhan-penyuluhan tentang pentingnya pemberian imunisasi dasar pada bayi.

Kata Kunci : Dukungan keluarga; Imunisasi; Keterjangkauan tempat pelayanan; Kepatuhan ibu; Pengetahuan

\section{PENDAHULUAN}

Imunisasi merupakan cara yang terbukti dapat mengendalikan dan menghilangkan penyakit menular yang mengancam jiwa dan diperkirakan dapat mencegah antara dua hingga tiga juta kematian setiap tahun. Ini adalah salah satu investasi kesehatan yang paling hemat biaya, dengan strategi yang telah dirancang agar dapat diakses dengan mudah oleh masyarakat. Kelompok sasaran imunisasi jelas, bisa disampaikan secara efektif melalui kegiatan sosialisasi, dan setelah imunisasi dapat melakukan aktivitas seperti biasa (World Health Organization, 2018).

Program imunisasi di Indonesia memberikan tujuh jenis vaksin yaitu BCG, DPT, Polio, Campak, Hepatitis B, TT dan DT (Rahardjo \& Marmi, 2018). Imunisasi merupakan suatu program yang dengan sengaja memasukkan antigen lemah agar merangsang antibodi keluar sehingga tubuh dapat resisten terhadap penyakit tertentu. Sistem imun tubuh mempunyai suatu sistem memori (daya ingat). Tubuh terpapar vaksin akan terbentuk antibodi melawan vaksin tersebut dan sistem memori akan menyimpannya sebagai suatu pengalaman, jika nantinya tubuh terpapar untuk kedua atau tiga kali oleh antigen yang sama dengan vaksin maka antibodi akan tercipta lebih kuat dari vaksin yang pernah dihadapi sebelumnya (Rahardjo \& Marmi, 2018).

Ratusan anak-anak dan orang dewasa setiap tahun di seluruh dunia meninggal karena penyakit yang sebenarnya masih dapat dicegah. Hal ini dikarenakan kurangnya informasi tentang pentingnya imunisasi. Semua golongan usia memiliki risiko tinggi terserang penyakit - penyakit menular yang mematikan. Imunisasi menjadi salah satu pencegahan yang terbaik dan sangat vital agar bayi-bayi, anakanak muda, dan orang dewasa terlindungi (Kemenkes RI, 2018).

Dalam peraturan pemerintah, lima jenis imunisasi dasar yang wajib diberikan pada bayi mulai dari umur 0 12 bulan yaitu imunisasi yang dapat mencegah penyakit antara lain TBC, difteri, tetanus, pertusis, poliomyelitis, campak dan hepatitis B. Imunisasi dasar lengkap yang wajib diperoleh bayi sebelum umur 1 tahun tersebut adalah imunisasi BCG yang dilakukan pada bayi usia 0-11 bulan dan hanya satu kali diberikan, imunisasi DPT yang diberikan 3 kali pada usia 2-11 bulan, imunisasi polio yang diberikan 4 kali pada usia 0-11 bulan, imunisasi campak yang diberikan 1 kali pada bayi usia 1-11 bulan (Hidayah et al., 2018).

Menurut data statistik kesehatan dunia 2018, cakupan imunisasi secara global untuk imunisasi DPT3 sebesar $84 \%$, HepB3 sebesar $81 \%$ dan campak sebesar $84 \%$ pada tahun 
2013, belum mencapai target imunisasi global yaitu sebesar $90 \%$ dari jumlah anak usia 0-12 bulan di dunia. Indonesia termasuk negara yang tidak mencapai target tersebut, dengan cakupan imunisasi DPT3 sebesar $85 \%$, HepB3 sebesar $85 \%$ dan campak sebesar $84 \%$ pada tahun 2015 (WHO, 2018). Oleh karena itu, dari 194 negara anggota WHO, 65 negara diantaranya memiliki cakupan imunisasi DPT3 dibawah target global 90\%, termasuk Indonesia (Kemenkes RI, 2018).

Berdasarkan data Kemetrian Kesehatan Republik Indonesia (2018) presentase pencapaian imunisasi lengkap Indonesia 86,9\% sedangkan untuk provinsi Sumatera Barat cakupan imunisasi dasar lengkap pada tahun 2018 hanya mencapai 79,1\%, lebih rendah dari pencapaian tingkat nasional, provinsi dengan cakupan imunisasi terendah adalah papua 45,0\% dan provinsi dengan cakupan imunisasi tertinggi adalah Kepulauan Riau 101,8\%.

Menurut data Dinas Kesehatan Kota (2018), terdapat tiga puskesmas dengan cakupan imunisasi dasar lengkap yang terendah diantara 22 puskesmas lainnya yaitu Puskesmas Lubuk Buaya sebesar 66,3\%, Puskesmas Anak Air sebesar 89,6\%, Puskesmas Padang Pasir sebesar 90,0\%. Dimana target pencapaian imunisasi di Kota Padang sebesar 95\%. Berdasarkan data tersebut dapat dilihat bahwa Puskesmas Lubuk Buaya merupakan puskesmas cakupan imunisasi dasar lengkap paling rendah dan untuk semua imunisasi belum tercapai target.

Berdasarkan survei awal yang peneliti lakukan pada tanggal 18 Januari 2020 di Puskesmas Lubuk Buaya Padang, peneliti mewawancari 10 orang ibu yang memiliki bayi didapatkan sebanyak 4 dari $10 \mathrm{ibu}$ yang diwawancarai mengatakan bahwa mereka tidak membawa anaknya imunisasi karena tidak mengetahui manfaat imunisasi serta takut efek samping yang dialami anak setelah mendapatkan imunisasi yaitu demam. Ibu juga mengatakan bahwa anak sebelumnya juga tidak diimunisasi dan masih sehat hingga saat ini. Sebanyak 3 dari 10 orang ibu mengatakan tidak mau mengimunisasi anaknya karena jarak rumah dengan pelayanan imunisasi jauh dan tidak ada transportasi ke pelayanan imunisasi. Sebanyak 3 dari 10 ibu juga mengatakan tidak mendapat dukungan dari keluarga dalam mengimunisasikan anaknya. Berdasarkan uraian di atas, peneliti tertarik untuk melakukan penelitian tentang "Faktor - Faktor yang Berhubungan dengan Kepatuhan Ibu dalam Melakukan Pemenuhan Imunisasi Dasar Pada bayi Usia 0 - 12 Bulan di Wilayah Kerja Puskesmas Lubuk Buaya Padang Tahun 2020”.

\section{METODE PENELITIAN}

Jenis penelitian ini adalah deskriktip analitik dengan desain penelitian cross sectional study. Penelitian ini dilaksanakan di Puskesmas Lubuk Buaya Padang pada tanggal 2 - 14 Maret 2020. Populasi pada penelitian ini adalah seluruh Ibu yang memiliki bayi usia 0-12 bulan di Wilayah Kerja Puskesmas Lubuk Buaya Padang dengan jumlah 1.332 orang sampel yang diambil sebanyak 93 orang. Kriteria inklusi : Ibu yang mempunyai buku KIA/KMS, Ibu bayi yang tinggal di Wilayah Kerja Puskesmas Lubuk Buaya Padang, Ibu yang memiliki anak usia $0-12$ bulan, bersedia ikut jadi responden dalam penelitian ini. Pada penelitian ini 
pengambilan sampel dilakukan dengan menggunakan teknik proporsional simple random sampling. Instrumen dalam penelitian ini adalah lembar kuisioner dan lembar observasi, pengolahan data melalui tahap editing, coding, entry, cleaning, tabulating dan analisa univariat dan bivariat dengan menggunakan uji chi-square dengan tingkat kepercayaan $\leq 0,05$.

\section{HASIL DAN PEMBAHASAN Analisa Univariat}

Tabel 1

Distribusi Frekuensi Responden Berdasarkan Kepatuhan Ibu dalam melakukan Pemenuhan Imunisasi Dasar pada Bayi 0 - 12 Bulan

\begin{tabular}{lll}
\hline Kepatuhan & $\boldsymbol{f}$ & $\mathbf{\%}$ \\
\hline Patuh & 41 & 44,1 \\
Tidak Patuh & 52 & 55,9 \\
\hline \multicolumn{1}{c}{ Total } & $\mathbf{9 3}$ & $\mathbf{1 0 0}$ \\
\hline
\end{tabular}

Berdasarkan tabel 1 di atas menunjukkan bahwa lebih dari separoh $(55,9 \%)$ responden tidak patuh dalam pemenuhan imunisasi dasar pada bayi $0-12$ bulan di Wilayah Kerja Puskesmas Lubuk Buaya Padang Tahun 2020, karena mereka masih menganggap bahwa imunisasi itu mengandung bahan yang tidak halal sehingga mereka takut untuk membawa bayinya kepuskesmas untuk melakukan imunisasi. Hasil penelitian ini sejalan dengan penelitian yang dilakukan Afriyantis (2016) dengan judul faktor-faktor yang berhubungan dengan kepatuhan masyarakat terhadap program imunisasi dasar Di Kabupaten Tegal, sebanyak $(56,2 \%)$ didapatkan bahwa ibu yang tidak patuh terhadap pemenuhan imunisasi.
Kepatuhan menyiratkan adanya suatu upaya untuk mengendalikan, walaupun hanya sebagian, pembuatan keputusan dipihak pasien. Kepatuhan telah diupayakan untuk menyeimbangkan permasalahan kendali ini dengan menggunakan istilah seperti mutual contracting (persetujuan bersama). Ditambahankan menurut Sarafino secara umum, ketidaktaatan meningkatkan resiko berkembangnya masalah kesehatan atau memperpanjang, atau memperburuk kesakitan yang sedang diderita (Niven Neil, 2012).

Tabel 2

\section{Distribusi Frekuensi Responden Berdasarkan Tingkat Pengetahuan Ibu}

\begin{tabular}{ccc}
\hline Pengetahuan & $\boldsymbol{f}$ & $\mathbf{\%}$ \\
\hline Tinggi & 13 & 14,0 \\
Sedang & 24 & 25,8 \\
Rendah & 56 & 60,2 \\
\hline Total & $\mathbf{9 3}$ & $\mathbf{1 0 0}$ \\
\hline
\end{tabular}

Berdasarkan tabel 2 di atas menunjukkan bahwa lebih dari separoh $(60,2 \%)$ responden dengan pengetahuan rendah pada ibu bayi di Wilayah Kerja Puskesmas Lubuk Buaya Padang, karena responden tidak mengetahui tentang imunisasi serta manfaatnya sehingga mereka kurang terpapar tentang pengetahuan seputar imunisasi. Hasil penelitian ini sejalan dengan penelitian yang dilakukan oleh Maryani (2017) dengan judul faktor-faktor yang mempengaruhi ketidakpatuhan ibu terhadap pelaksanaan imunisasi pada balita di Desa Blumbang Kabupaten Karanganyar, sebanyak $60 \%$ ibu dengan tingkat pengetahuan yang rendah. 
Pengetahuan (knowledge atau ilmu) adalah bagian yang esensialaksiden manusia Pengetahuan manusia diperoleh melalui persepsinya terhadap stimulus dengan menggunakan alat indra, hasil persepsi berupa informasi akan disimpan dalam sistem memori untuk diolah dan diberikan makna, selanjutnya informasi tersebut digunakan (retrieval) pada saat diperlukan (Notoadmojo, 2013).

Tabel 3

\section{Distribusi Frekuensi Responden Berdasarkan Keterjangkauan Tempat Pelayanan Imunisasi}

\begin{tabular}{|c|c|c|}
\hline $\begin{array}{c}\text { Keterjangkauan Tempat } \\
\text { Pelayanan Imunisasi }\end{array}$ & $f$ & $\%$ \\
\hline Dekat & 66 & 71,0 \\
\hline Jauh & 27 & 29,0 \\
\hline Total & 93 & 100 \\
\hline
\end{tabular}

Berdasarkan tabel 3 di atas menunjukkan bahwa lebih dari separoh $(71,0 \%)$ responden dengan keterjangkauan tempat pelayanan imunisasi dengan jarak dekat di Wilayah Kerja Puskesmas Lubuk Buaya Padang, karena responden memiliki jarak rumah yang dekat dengan puskesmas lebih banyak. Hasil penelitian ini sejalan dengan penelitian yang dilakukan Afriyantis (2016) dengan judul faktor-faktor yang berhubungan dengan kepatuhan masyarakat terhadap program imunisasi dasar Di Kabupaten Tegal, sebanyak $(56,2 \%)$ ibu yang memiliki jarak rumah dekat dengan pelayanan imunisasi (posyandu).

Ketersediaan dan keterjangkauan sumber daya kesehatan termasuk tenaga kesehatan yang ada dan mudah dijangkau merupakan salah satu faktor yang member kontribusi terhadap perilaku dalam mendapatkan pelayanan kesehatan. Faktor pendukung lain menurut Rizka et al. (2015) adalah akses terhadap pelayanan kesehatan yang berarti bahwa pelayanan kesehatan tidak terhalang oleh keadaan geografis, keadaan geografis ini dapat diukur dengan jenis transportasi, jarak, waktu perjalanan dan hambatan fisik lain yang dapat menghalangi seseorang mendapat pelayanan kesehatan. Semakin kecil jarak jangkauan masyarakat terhadap suatu tempat pelayanan kesehatan, maka akan semakin sedikit pula waktu yang diperlukan sehingga tingkat pemanfaatan pelayanan kesehatan meningkat.

Tabel 4

Distribusi Frekuensi Responden Berdasarkan Dukungan Keluarga Dalam Pemenuhan Imunisasi Pada Bayi 0 - 12 Bulan

\begin{tabular}{lcc}
\hline Dukungan Keluarga & $\boldsymbol{f}$ & $\mathbf{\%}$ \\
\hline Mendukung & 40 & 43 \\
Tidak Mendukung & 53 & 57 \\
$\quad$ Total & $\mathbf{9 3}$ & $\mathbf{1 0 0}$ \\
\hline
\end{tabular}

Berdasarkan tabel 4 di atas menunjukkan bahwa lebih dari separoh $(57 \%)$ responden dengan dukungan keluarga tidak mendukung untuk melakukan imunisasi dasar pada bayi $0-12$ bulan di Puskesmas Lubuk Buaya Padang, karena keluarga cendrung memiliki pemahaman yang salah terhadap imunisasi, sehingga mereka tidak mau memberikan dukungan positif untuk melakukan imunisasi. Hasil penelitian ini sejalan dengan penelitian yang dilakukan oleh Maryani (2017) dengan judul faktor-faktor yang mempengaruhi ketidakpatuhan ibu terhadap pelaksanaan imunisasi pada 
Balita Di Desa Blumbang Kabupaten Karanganyar, sebanyak $60 \%$ dengan dukungan keluarga tidak mendukung.

Keluarga adalah kumpulan dua atau lebih individu yang berbagai tempat tinggal atau berdekatan dengan yang lainnya, memiliki ikatan emosi, terlihat dalam posisi sosial, peran dan tugas-tugas yang saling berhubungan, serta adanya rasa saling menyayangi dan memiliki (Friedman, 2010).

\section{Analisa Bivariat}

\section{Tabel 5}

Hubungan Pengetahuan dengan Kepatuhan Pada Pemenuhan Imunisasi Dasar Bayi 0 - 12 Bulan

\begin{tabular}{lccccccc}
\hline \multirow{2}{*}{ Pengetahuan } & \multicolumn{4}{c}{ Kepatuhan } & & \multirow{2}{*}{ Total } & p-value \\
\cline { 2 - 5 } & \multicolumn{3}{c}{ Patuh } & \multicolumn{2}{c}{ Tidak Patuh } & & \\
& $\boldsymbol{f}$ & $\mathbf{\%}$ & $\boldsymbol{f}$ & $\mathbf{\%}$ & $\boldsymbol{f}$ & $\mathbf{\%}$ & \\
\hline Tinggi & 10 & 76,9 & 3 & 23,1 & 13 & 100 & $\mathbf{0 . 0 1 9}$ \\
Sedang & 7 & 29,2 & 17 & 70,8 & 24 & 100 & \\
Rendah & 24 & 42,9 & 32 & 57,1 & 56 & 100 & \\
\hline Total & $\mathbf{4 1}$ & $\mathbf{4 4 , 1}$ & $\mathbf{5 2}$ & $\mathbf{5 5 , 9}$ & $\mathbf{9 3}$ & $\mathbf{1 0 0}$ & \\
\hline
\end{tabular}

Berdasarkan tabel 5 dapat dilihat bahwa dari 93 responden terdapat 13 responden yang memiliki pengetahuan tinggi dan didapatkan tidak patuh menjalani imunisasi yaitu $3(23,1 \%)$. Sementara dari 24 responden dengan pengetahuan sedang dan terdapat 17 $(70,8 \%)$ responden tidak patuh. Sedangkan 56 responden dengan pengetahuan rendah terdapat $(57,1 \%)$ yang tidak patuh dalam menjalankan imunisasi. Berdasarkan hasil uji ChiSquare menunjukkan $p$ value $=0,019$ $(p \leq 0,05)$, ini berarti ada hubungan tingkat pengetahuan dengan kepatuhan ibu dalam melakukan pemenuhan imunisasi dasar pada bayi usia 0-12 bulan di Wilayah Kerja Puskesmas Lubuk Buaya Padang.

Hasil penelitian ini sejalan dengan penelitian yang dilakukan oleh Maryani (2017) dengan judul faktor-faktor yang mempengaruhi ketidakpatuhan ibu terhadap pelaksanaan imunisasi balita di Desa Blumbang Kecamatan Tawamangung Kabupaten Karanganyar didapatkan hasil uji logistik untuk variabel pengetahuan diperoleh nilai koefisien regresi pengetahuan dengan ketidakpatuhan adalah 0,775. Nilai koefisien regresi yang positif (+) menunjukkan arah hubungan pengetahuan dengan ketidakpatuhan adalah searah, yaitu semakin baik pengetahuan responden maka semakin tinggi ketidakpatuhannya melaksanakan imunisasi. Selanjutnya hasil uji wald test diperoleh nilai Wald hitung sebesar 6,802 dengan probabilitas 0,009. Berdasarkan nilai probabilitas tersebut dapat disimpulkan bahwa terdapat pengaruh yang signifikan tingkat pengetahuan terhadap ketidakpatuhan.

Berdasarkan analisa peneliti didapatkan juga bahwa ibu dengan pengetahuan tinggi namun tidak patuh menjalani program imunisasi yaitu $23,1 \%$ hal ini dapat terjadi karena ratarata ibu dengan pengetahuan tinggi memiliki banyak rutinitas dan kesibukan di dunia pekerjaan yaitu sebanyak 14,3 $\%$ sehingga mereka tidak memiliki waktu yang banyak untuk membawa anaknya kepelayanan kesehatan untuk imunisasi. Sementara ibu dengan pengetahuan rendah namun patuh 
imunisasi $42,9 \%$ hal ini dapat terjadi karena ibu memiliki banyak waktu dirumah sehingga tidak ada alasan bagi mereka untuk tidak membawa bayinya ke pelayanan kesehatan untuk mendapatkan imunisasi serta jarak rumah yang dekat dengan pelayanan kesehatan serta dukungan keluarga yang cukup baik. Sehingga dapat mempengaruhi ibu untuk rutin melakukan imunisasi terhadap bayinya.

\section{Tabel 6}

\section{Hubungan Keterjangkauan Tempat Pelayanan Imunisasi dengan Kepatuhan} Ibu Pada Pemenuhan Imunisasi Dasar Bayi 0 - 12 Bulan

\begin{tabular}{|c|c|c|c|c|c|c|c|}
\hline \multirow{3}{*}{$\begin{array}{c}\text { Keterjangkauan } \\
\text { tempat } \\
\text { pelayanan } \\
\text { imunisasi }\end{array}$} & \multicolumn{4}{|c|}{ Kepatuhan } & \multirow{2}{*}{\multicolumn{2}{|c|}{ Total }} & \multirow{3}{*}{ p-value } \\
\hline & \multicolumn{2}{|c|}{ Patuh } & \multicolumn{2}{|c|}{ Tidak Patuh } & & & \\
\hline & $f$ & $\%$ & $f$ & $\%$ & \multicolumn{2}{|c|}{$f \quad \%$} & \\
\hline Dekat & 31 & 47 & 35 & 53 & 66 & 100 & 0.518 \\
\hline Jauh & 10 & 37 & 17 & 63 & 27 & 100 & \\
\hline Total & 41 & 44,1 & 52 & 55,9 & 93 & 100 & \\
\hline
\end{tabular}

Berdasarkan tabel 6 dapat dilihat bahwa dari 93 responden dengan keterjangkauan tempat pelayanan imunisasi dekat namun tidak patuh yaitu (53\%) dibandingkan dengan responden yang patuh yaitu $(47 \%)$. Sementara dari 27 responden dengan keterjangkauan tempat pelayanan imunisasi jauh namun patuh yaitu (37\%) dibandingan dengan tidak patuh (63\%). Berdasarkan hasil uji Chi-Square menunjukkan $p$ value $=$ $0,518$ ( $\mathrm{p} \leq 0,05)$, ini berarti tidak ada hubungan keterjangkauan tempat pelayanan imunisasi dengan kepatuhan ibu dalam melakukan pemenuhan imunisasi dasar pada bayi usia 0-12 bulan di Wilayah Kerja Puskesmas Lubuk Buaya Padang.

Hasil penelitian ini sama dengan penelitian yang dilakukan oleh Rizka et al (2015) dengan hasil penelitian menunjukkan bahwa tidak ada hubungan antara keterjangkauan ke tempat pelayanan imunisasi dengan kelengkapan imunisasi dasar pada bayi di Desa Kumpulrejo Kecamatan Argomulyo Kota Salatiga. Hal ini didasarkan pada hasil analisis dengan uji chi square diperoleh $p$ value $=0,573(p$ value $>0,05)$.
Analisa peneliti didapatkan bahwa $33 \%$ responden yang jarak rumahnya dekat dengan pelayanan imunisasi namun tidak patuh membawa anaknya untuk imunisasi rutin karena mereka masih berfikir bahwa imunisasi itu mengandung bahan yang tidak halal dan nanti bisa berdampak kepada pertumbuhan dan perkembangan anak bahkan bisa menyebabkan demam dan bisa membuat pekerjaan mereka menjadi bertambah. Sebagian besar responden memiliki kesibukan dan tidak adanya dukungan dari berbagai pihak untuk rutin membawa bayinya kepelayanan imunisasi meski jaraknya dekat. Sementara itu 37\% ibu dengan jarak pelayanan imunisasi jauh namun patuh membawa balitanya imunisasi setiap bulannya. Hal ini disebabkan jarak puskesmas yang relatif terjangkau dari rumah dan pengaruh angkutan umum seperti ojek, angkot dan lain-lain yang mudah didapat sehingga dapat mengurangi hambatan waktu. Letak tempat pelayanan imunisasi berada di tempat yang mudah didatangi masyarakat, sehingga tidak menyulitkan masyarakat untuk mengimunisasikan anaknya. 
Tabel 7

Hubungan Dukungan Keluarga dengan Kepatuhan Ibu Pada Pemenuhan Imunisasi Dasar Bayi 0 - 12 Bulan

\begin{tabular}{|c|c|c|c|c|c|c|c|}
\hline \multirow[t]{3}{*}{ Dukungan Keluarga } & \multicolumn{4}{|c|}{ Kepatuhan } & \multirow{2}{*}{\multicolumn{2}{|c|}{ Total }} & \multirow{3}{*}{$\underset{\text { value }}{\mathbf{p}}$} \\
\hline & \multicolumn{2}{|c|}{ Patuh } & \multicolumn{2}{|c|}{ Tidak Patuh } & & & \\
\hline & $f$ & $\%$ & $f$ & $\%$ & $f$ & $\%$ & \\
\hline Mendukung & 24 & 60 & 16 & 40 & 40 & 100 & 0.013 \\
\hline Tidak Mendukung & 17 & 32,1 & 36 & 67,9 & 53 & 100 & \\
\hline Total & 41 & 44,1 & 52 & 55,9 & 93 & 100 & \\
\hline
\end{tabular}

Berdasarkan tabel 7 dapat dilihat bahwa dari 93 responden dengan dukungan keluarga mendukung namun tidak patuh yaitu $(40 \%)$ dibandingkan dengan responden yang patuh $(60 \%)$. Sementara dari 53 responden dengan dukungan keluarga tidak mendukung namun patuh yaitu $(32,1 \%)$ dibandingan dengan responden tidak patuh $(67,9 \%)$. Berdasarkan hasil uji Chi-Square menunjukkan $p$ value $=0,013$ $(\mathrm{p} \leq 0,05)$, ini berarti ada hubungan dukungan keluarga dengan kepatuhan ibu dalam melakukan pemenuhan imunisasi dasar pada bayi usia 0-12 Bulan di Wilayah Kerja Puskesmas Lubuk Buaya Padang.

Hasil penelitian ini sejalan dengan yang dilakukan oleh Rizka et al (2015) dengan hasil analisis yang diperoleh dari uji chi square menunjukan bahwa $p$ value $=0,003$ $(\mathrm{p} \leq 0,05)$, sehingga Ha diterima, yang artinya ada hubungan antara dukungan keluarga dengan kelengkapan imunisasi dasar pada bayi di Desa Kumpulrejo Kecamatan Argomulyo Kota Salatiga.

Perhitungan risk estimate, diperoleh nilai odd ratio $(\mathrm{OR})=$ 5,714, sehingga dapat disimpulkan bahwa responden yang tidak didukung keluarga untuk mengimunisasikan anaknya memiliki risiko 3,455 kali tidak memberikan imunisasi dasar lengkap kepada anaknya dibandingkan dengan responden yang didukung keluarga untuk mengimunisasikan anaknya.

Analisa peneliti didapatkan bahwa $40 \%$ yang mendapatkan dukungan dari keluarga namun tidak patuh dalam menjalankan program imunisasi. Hal ini dapat terjadi karena ibu masih kurang pengetahuan tentang pentingnya imunisasi serta jarak rumah yang jauh dari pelayanan imunisasi juga mempengaruhi ibu tidak patuh terhadap pelayanan imunisasi tersebut. Selain itu 32,1\% tidak mendapat dukungan keluarga namun patuh menjalankan program imunisasi. Hal ini dapat terjadi karena pemahaman ibu akan pentingnya imunisasi serta tingkat pengetahuan ibu yang tinggi serta rutinitas ibu yang dapat disesuaikan dengan kebutuhan anak, mejadi faktor penyebab ibu patuh melakukan imunisasi terhadap anaknya.

\section{SIMPULAN}

Berdasarkan hasil penelitian dan pembahasan di atas maka dari penelitian ini dapat disimpulkan beberapa hal yaitu sebagai berikut : Lebih dari separoh ibu tidak patuh dalam melakukan pemenuhan imunisasi dasar pada bayi $0-12$ bulan, lebih dari separoh ibu dengan pengetahuan rendah dalam melakukan pemenuhan imunisasi dasar pada bayi $0-12$ bulan, Lebih dari separoh ibu dengan keterjangkauan tempat pelayanan imunisasi dekat dalam 
pemenuhan imunisasi dasar pada bayi $0-12$ bulan, lebih dari separoh ibu dengan dukungan keluarga tidak mendukung pemenuhan imunisasi dasar pada bayi $0-12$ bulan. Terdapat hubungan antara pengetahuan dengan kepatuhan ibu dalam melakukan pemenuhan imunisasi dasar pada bayi 0-12 Bulan. Tidak terdapat hubungan antara keterjangkauan tempat pelayanan imunisasi dengan kepatuhan ibu dalam melakukan pemenuhan imunisasi dasar pada bayi 0-12 Bulan. terdapat hubungan antara dukungan keluarga dengan kepatuhan ibu dalam melakukan pemenuhan imunisasi dasar pada bayi 0-12 Bulan.

\section{UCAPAN TERIMA KASIH}

Pelaksanaan kegiatan ini tidak terlepas dari bantuan dan dukungan dari berbagai pihak. Pada kesempatan ini kami mengucapkan terima kasih kepada Pimpinan Puskesmas Lubuk Buaya Padang, Yayasan dan STIKes MERCUBAKTIJAYA Padang, LPPM STIKes MERCUBAKTIJAYA Padang yang telah membantu dan memfasilitasi kegiatan penelitian.

\section{DAFTAR PUSTAKA}

Afriyantis. (2016). Faktor - Faktor Yang Berhubungan Dengan Kepatuhan Masyarakat Terhadap Program Imunisasi Dasar Di Kabupaten Tegal. E-Journal Keperawatan, 2(6).

Kementrian Kesehatan Republik Indonesia. (2018). Profil Kesehatan Indonesia.

Dinas Kesehatan Kota. (2018). Laporan Dinas Kesehatan Kota Padang.

Friedman, M. (2010). Buku Ajar keperawatan Keluarga: Riset, Teori Dan Praktik (5th ed.). Jakarta : EGC.
Hidayah, N., Sitohang, H. ., \& Lestari, W. (2018). Faktor Faktor Yang Berhubungan Dengan Pemberian Imunisasi Dasar Lengkap Pada Bayi. Journal Akademi Kebidanan Sempena Negeri Pekanbaru.

Maryani. (2017). Faktor - Faktor Yang Mempengaruhi Ketidakpatuhan Ibu Terhadap pelaksanaan Imunisasi Pada Balita Di Desa Blumbang Kabupaten Karang Anyar. EJournal Keperawatan, 5(2).

Niven Neil. (2012). Psikologi Kesehatan. Jakarta : EGC.

Notoadmojo. (2013). Metodologi Penelitian Kesehatan. Jakarta : Rineka Cipta.

Rahardjo, K., \& Marmi. (2018). Asuhan Neonatus Bayi Balita dan Anak Pra Sekolah. Jakarta : Pustaka Pelajar.

Rizka, Y., Winarsih, S., \& Imavike, F. (2015). Hubungan Peran Orang Tua Dalam Pemberian Imunisasi Dasar Dengan Status Imunisasi Bayi Di Desa Wilayah kerja Puskesmas Dringu Kabupaten Probolinggo. Journal Ilmu Keperawatan, 1(2).

World Health Organization. (2018). Status Imunisasi Dasar Anak Di Indonesia. 